\title{
Geologic and geomorphologic studies on distribution of Simulium ochraceum (Diptera: Simuliidae) larvae in Guatemala*
}

\author{
Yoichi Yamagata, ${ }^{* *}$ Takao Okazawa ${ }^{* * *}$ and Pedro Antonio Molina \\ Laboratorio de Investigación Científica para Control de la Oncocercosis, SNEM, \\ 5a. Avenida 11-40, Zona 11, Guatemala, Guatemala
}

(Received: May 25, 1983)

Key words: Simulium ochraceum, larval distribution, Guatemala, geology, geomorphology.

\begin{abstract}
On-foot surveys were made for the purpose of mapping perennial streams infected with Simulium ochraceum in an endemic area of onchocerciasis in Guatemala. Of 246 perennial streams $(144.4 \mathrm{~km})$ found in $477 \mathrm{~km}^{2}, 119(48.4 \%)$ or $27.8 \mathrm{~km}(19.3 \%)$ were found infested with $S$. ochraceum. S. ochraceum larvae were found mainly from older impermeable rocks such as Tertiary lahars and lavas, arkosic conglomerate and Cretaceous granite. Although recent volcanic rocks have very few perennial streams due to permeability, they are important as water reservoirs for the underlying impermeable rocks. Quarternary alluvium showed high stream density, but no $S$. ochraceum larva was found from these streams, due probably to small channel slope. The area with Tertiary lahars and lavas is the most important bed of ochraceum-breeding streams, which roughly coincides with the onchocerciasis endemic area. Of total 1469 channel segments in this area, only $203(13.8 \%)$ had perennial streams, of which $108(53.2 \%)$ were infested with $S$. ochraceum. With increment of the channel order, the raito of channel segments with perennial streams increased, while, on the contrary, the ratio of perennial streams with $S$. ochraceum larvae decreased. No $S$. ochraceum larva was found in the fourth and fifth order channels. S. ochraceum larvae were found mainly in the uppermost part of the stream network, immediately below headsprings. The headsprings were found arranged nearly horizontally on the elevations $900 \mathrm{~m}, 1100 \mathrm{~m}$ and $1300-1460 \mathrm{~m}$ above sea level.
\end{abstract}

* This study was supported by the Ministry of Health and Public Assistance, Guatemala and Japan International Cooperation Agency, Japan (ORCOP Series No. 51).

** 山形洋一

*** Present address: Department of Microbiology, Saga Medical School, Nabeshima, Saga 84001, Japan.

岡沢孝雄：（現住所）佐賀医科大学微生物学教室 (下840-01 佐賀市鍋島大字鍋島三本杉)

\section{INTRODUCTION}

Simulium ochraceum is the principal vector of human onchocerciasis in Guatemala and Mexico, where larval control of $S$. ochraceum is very difficult because of its peculiar breeding preference on minute streamlets. Pessimistic views had been the main current on this subject (McMahon, 
1967; Crosskey, 1973; Davies, 1974) until Nakamura et al. (1981) reported the first success in reducing fly density of $S$. ochraceum in Guatemala by the use of temephos as a larviciding agent. Their trial had an advantage in settling a small control area (3 $\mathrm{km}^{2}$ ) where breeding sites were well known. Such lucky situaiton, however, is not usual in Guatemala, and overlooking of breeding streams is the major problem of control operation. The control scheme of Nakamura et al. (1981) was not satisfactorily applied to the adjacent basin (Takaoka et al., 1981).

The present study was carried out from 1977 to 1983 in a part of the pilot area of the Guatemala-Japan Cooperative Project on Onchocerciasis Research and Control in Guatemala. Main purpose of this study was to prepare detailed map for larviciding operation in the study area, based on geologic and geomorphologic knowledges, as well as to improve survey methodology applicable to other endemic foci in Guatemala.

\section{Materials and Methods}

The topographic map "Amatitlán" and the geologic map "Amatitlán", both in $1: 50,000$ scale published by the Instituto Geográfico Nacional, Guatemala, were employed as the basic information of the study area. The geologic map describes 28 rock units in this area, most of which are Quaternary and Tertiary volcanic rocks (Table 1 ).

The drainage map was made from the topographic map by means of tracing $\mathrm{V}$ indentations of the contour lines. The channel segments were classified into orders according to the definition by Horton (1945) and its modification by Strahler (1957): The finger-tip tributaries of the channel network are designated the first order. Where two channel segments of the $i$ 'th order join, a segment of the $i+1^{\prime}$ th order is formed. A channel undetectable in the topographic map is called the 0'th order. Orders with greater code number are called higher orders. The term "channel order" is adopted in this text instead of the original term "stream order" by Horton and Strahler, so that clear distinction will be made between "channel" in the geomorphologic term and "stream" in
Table 1 List of rock units in the study area $\mathbf{A} .^{1)}$

\begin{tabular}{|c|c|c|}
\hline Symbol & Rock unit & Landform \\
\hline \multicolumn{3}{|c|}{ Quaternary } \\
\hline$Q b$ & Basalt & Composite cones \\
\hline Qad & $\begin{array}{l}\text { Andesite and } \\
\text { dacite }\end{array}$ & Domes \\
\hline Qr-d & $\begin{array}{l}\text { Rhyodacite and } \\
\text { dacite }\end{array}$ & Domes and flows \\
\hline Qcc & Basalt & Cinder cones \\
\hline Qva & $\begin{array}{l}\text { Andesite and } \\
\text { lahars }\end{array}$ & Composite cones \\
\hline Qp & $\begin{array}{l}\text { Dacite and rhyo- } \\
\text { dacite }\end{array}$ & Pumice plateau \\
\hline Qac & Andesite & Ancestral volcano \\
\hline $\mathrm{Qa}$ & Alluvium & Plains \\
\hline \multicolumn{3}{|c|}{ Tertiary } \\
\hline $\mathrm{Ta}$ & Andesite & Fault scarps \\
\hline Ti-a & Lahars and lavas & $\begin{array}{l}\text { Rugged moun- } \\
\text { tains }\end{array}$ \\
\hline $\mathrm{Ti}$ & Andesite & Intrusions \\
\hline $\mathrm{Tc}$ & $\begin{array}{l}\text { Arkosic conglome- } \\
\text { rates }\end{array}$ & Fault scarps \\
\hline \multicolumn{3}{|c|}{ Cretaceous } \\
\hline $\mathrm{Kg}$ & Biotite granite & Fault scarps \\
\hline
\end{tabular}

1) Geologic symbols and legends were cited from the geologic map "Amatitlán", 1:50,000, Instituto Geográfico Nacional, Guatemala, with modifications. $\mathrm{Qb}$ in this table includes $\mathrm{Mb1}$, Mb2, Mb3, Mb, Mc, Mch, Hb1, Hb2, Hb3, Hb, Hp-c, Qpcf, Qpc, Qb and Qic, which are thus distinguished in the original map according to the time of erruption. Qva in this table includes parasitic cones (Qpa) in the original map.

the hydrologic term.

The initial field surveys were made in a rectangular area belonging to the Departments of Escuintla and Guatemala, Republic of Guatemala (the study area A in Fig. 1, $14^{\circ} 20^{\prime}-14^{\circ} 30^{\prime}$ N., $90^{\circ} 30^{\prime}-90^{\circ} 45^{\prime}$ W., ca. 500 $\mathrm{km}^{2}$ ). Streams shown in the topographic map were traced to discover their tributaries. Detailed field surveys were made in the southwestern quarter (the study area $\mathrm{B}$ in Fig. $1,14^{\circ} 20^{\prime}-14^{\circ} 25^{\prime}$ N., $90^{\circ} 37^{\prime}-90^{\circ} 45^{\prime}$ W., ca. $77 \mathrm{~km}^{2}$ ), where all the channel segments were meticulously visited. Blackfly larvae were collected for 10 minutes at every stream segment, and specimens were preserved in $70 \%$ ethanol solution for later identification 
in laboratory.

\section{Results}

Geologic aspects of distribution of S. ochraceum larvae in the study area $A$

After detailed on-foot surveys, 246 perennial streams with total length of $144.4 \mathrm{~km}$ were found from the study area $\mathrm{A}$. Of these streams, $119(48.4 \%)$ with total length of $27.8 \mathrm{~km}(19.3 \%)$ were infested with $S$. ochraceum larvae. Figure 1 shows the distribution of perennial streams, both with and without $S$. ochraceum larvae, with reference to geology. The ochraceum-breeding streams were found only in three rather small regions: (1) Ti-a area and adjacent part of Qp on the southwestern quarter of the study area ( $c a .77$ $\mathrm{km}^{2}$ ), (2) Tc and adjacent part of Ta on the northeastern corner $\left(1 \mathrm{~km}^{2}\right)$, and (3) $\mathrm{Kg}$ and adjacent part of Ta about $5 \mathrm{~km}$ south of the former $\left(2 \mathrm{~km}^{2}\right)$.

Table 2 shows the number, length and density of perennial streams and ochraceumbreeding streams on different rock units. $S$. ochraceum larvae were found from only five rock units ( $\mathrm{Qp}, \mathrm{Ta}, \mathrm{Ti}-\mathrm{a}, \mathrm{Tc}$ and $\mathrm{Kg}$ ) of total 13 in the area. Of these five, Qp and $\mathrm{Ta}$ hold ochraceum-breeding streams exclusively above the contacts with underlying $\mathrm{Ti}-\mathrm{a}, \mathrm{Tc}$ or $\mathrm{Kg}$.

The density of ochraceum-breeding streams was highest in $\mathrm{Kg}\left(2.80 \mathrm{~km}^{-1}\right)$, followed by Tc (0.58) and Ti-a (0.22). As to the total length of the ochraceum-breeding streams, Ti-a alone contributed as much as $75.9 \%$ of whole area, though its area is only $20.2 \%$. Furthermore, Ti-a together with adjacent part of Qp covered $87.4 \%$ of the whole ochraceum-breeding streams.

$\mathrm{Ti}-\mathrm{a}, \mathrm{Tc}$ and $\mathrm{Kg}$, the three principal ochraceum-breeding rock units, are characterized as impermeable older rocks. They can maintain even small amount of running water. On the other hand, permeable volcanic rocks showed low density of perennial streams. Although the recent volcanic cones (Qb, Qcc, Qva and Qac) occupy as much as $33.1 \%$ of the whole study area, only two streams were found there due to high permeability. Among the rest of permeable rock units, $Q p$ and $T a$ have perennial streams

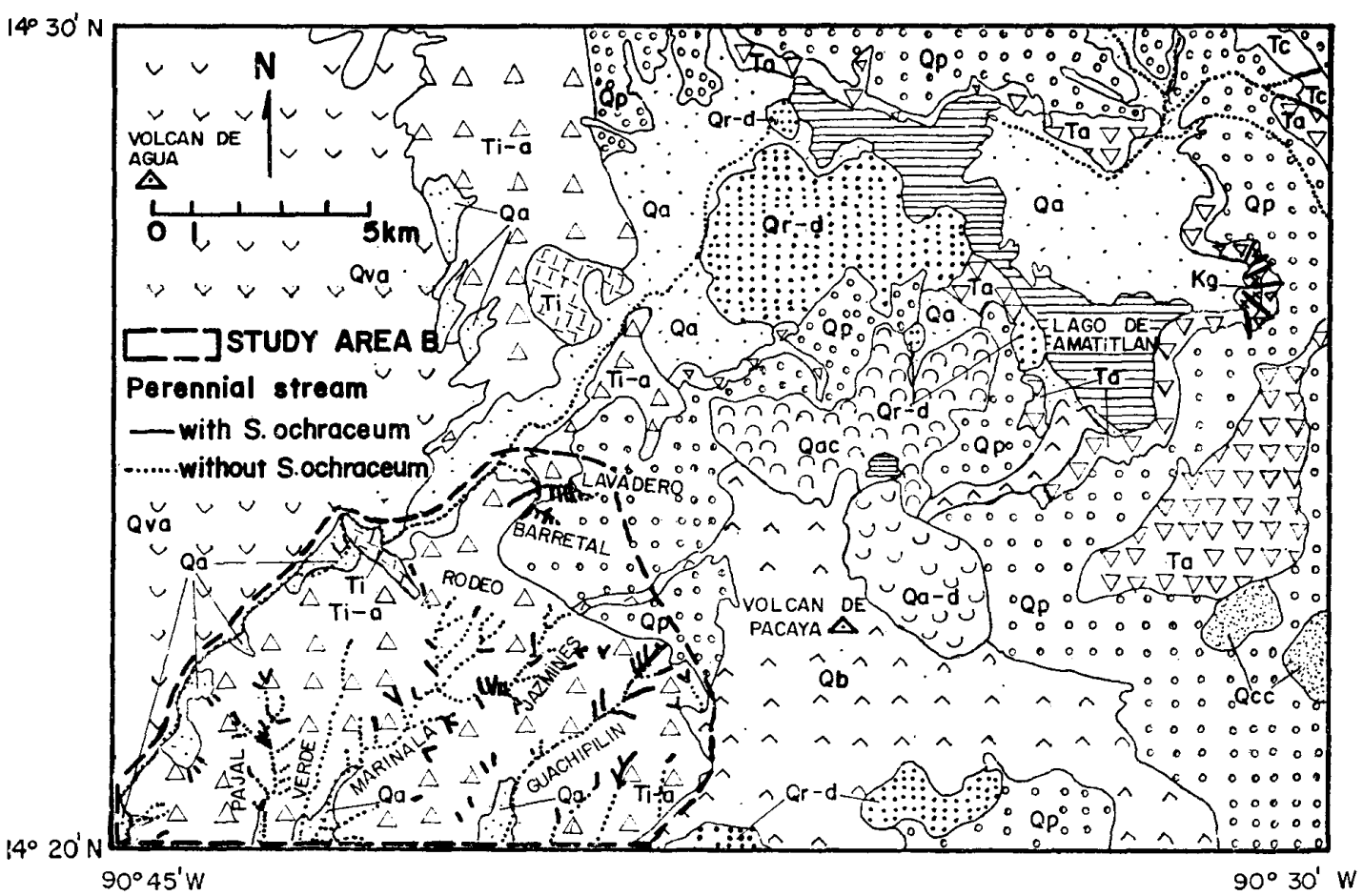

Fig. 1 A geologic map of the study area A, showing the distribution of perennial streams both with and without $S$. ochraceum larvae. (Partly reproduced from the geologic map "Amatitlán" with permission of the Instituto Geográfico Militar, Ejército de Guatemala.) Geologic symbols are explained in Table 1. 
Table 2 Number, length and density of perennial streams and ochraceum-breeding perennial streams on different rock units in the study area A.

\begin{tabular}{|c|c|c|c|c|c|c|c|c|c|c|c|c|c|}
\hline \multirow{3}{*}{$\begin{array}{l}\text { Rock } \\
\text { unit }^{1)}\end{array}$} & \multirow{3}{*}{$\begin{array}{c}\text { Permea- } \\
\text { bility }^{2}\end{array}$} & \multicolumn{2}{|c|}{ Area } & \multicolumn{4}{|c|}{ Perennial stream } & \multicolumn{4}{|c|}{$\begin{array}{l}\text { ochraceum-breeding } \\
\text { Perennial stream }\end{array}$} & \multicolumn{2}{|c|}{$\underset{(\%)}{\text { Ratio }}$} \\
\hline & & \multirow{2}{*}{$\mathrm{km}^{2}$} & \multirow{2}{*}{$(\%)$} & \multirow{2}{*}{$\begin{array}{l}\text { No. } \\
\text { (A) }\end{array}$} & \multicolumn{2}{|c|}{ Length (B) } & \multirow{2}{*}{$\begin{array}{c}\text { Density } \\
\mathrm{km}^{-1}\end{array}$} & \multirow{2}{*}{$\begin{array}{l}\text { No. } \\
\text { (C) }\end{array}$} & \multicolumn{2}{|c|}{ Length (D) } & \multirow{2}{*}{$\begin{array}{c}\text { Density } \\
\mathrm{km}^{-1}\end{array}$} & \multirow{2}{*}{$\mathrm{C} / \mathrm{A}$} & \multirow{2}{*}{$\mathrm{D} / \mathrm{B}$} \\
\hline & & & & & $\mathrm{km}$ & $(\%)$ & & & $\mathrm{km}$ & $(\%)$ & & & \\
\hline $\mathrm{Qa}$ & + & 52.2 & 10.9 & 13 & 72.7 & 50.3 & 1.39 & 0 & 0.0 & 0.0 & 0.00 & 0.0 & 0.0 \\
\hline $\mathrm{Qb}$ & ++ & 52.3 & 11.0 & 1 & 1.0 & 0.7 & 0.02 & 0 & 0.0 & 0.0 & 0.00 & 0.0 & 0.0 \\
\hline Qad & - & 8.2 & 1.7 & 0 & 0.0 & 0.0 & 0.00 & 0 & 0.0 & 0.0 & 0.00 & - & - \\
\hline Qr-d & - & 20.9 & 4.4 & 1 & 1.0 & 0.7 & 0.05 & 0 & 0.0 & 0.0 & 0.00 & 0.0 & 0.0 \\
\hline Qcc & ++ & 2.5 & 0.5 & 0 & 0.0 & 0.0 & 0.00 & 0 & 0.0 & 0.0 & 0.00 & - & 一 \\
\hline Qva & + & 89.0 & 18.7 & 1 & 6.9 & 4.8 & 0.08 & 0 & 0.0 & 0.0 & 0.00 & 0.0 & 0.0 \\
\hline Qp & ++ & 105.9 & 22.2 & 17 & 12.6 & 8.7 & 0.12 & 9 & 3.2 & 11.5 & 0.03 & 52.9 & 25.4 \\
\hline Qac & + & 13.8 & 2.9 & 0 & 0.0 & 0.0 & 0.00 & 0 & 0.0 & 0.0 & 0.00 & - & - \\
\hline $\mathrm{Ta}$ & + & 30.6 & 6.4 & 7 & 2.4 & 1.7 & 0.08 & 5 & 1.4 & 5.0 & 0.05 & 71.4 & 58.3 \\
\hline Ti-a & $-\left(+^{4}\right)$ & 96.1 & 20.2 & 196 & 44.6 & 30.9 & 0.46 & 99 & 21.1 & 75.9 & 0.22 & 50.5 & 47.3 \\
\hline $\mathrm{Ti}$ & + & 3.6 & 0.8 & 2 & 0.5 & 0.3 & 0.14 & 0 & 0.0 & 0.0 & 0.00 & 0.0 & 0.0 \\
\hline $\mathrm{Tc}_{\mathrm{c}}$ & - & 1.2 & 0.3 & 2 & 0.9 & 0.6 & 0.75 & 2 & 0.7 & 2.5 & 0.58 & 100.0 & 77.8 \\
\hline $\mathrm{Kg}$ & - & 0.5 & 0.1 & 6 & 1.8 & 1.2 & 3.60 & 4 & 1.4 & 5.0 & 2.80 & 66.7 & 77.8 \\
\hline Tota & & 476.8 & 100.0 & 246 & 144.4 & 100.0 & 0.30 & 119 & 27.8 & 100.0 & 0.06 & 48.4 & 19.3 \\
\hline
\end{tabular}

1) Rock unit abbreviations are explained in Table 1.

2) Permeability was roughly estimated in the field by the proportion between rainfall and surface runoff.

3) Stream density $=$ Total stream length/Area.

4) Ti-a is composed of impermeable lahars and permeable lavas.

almost exclusively above the contact with underlying impermeable rocks.

Although permeable rocks are not adequate for stream beds, they play an important role as aquifer or groundwater reservoir when they overlie impermeable rocks. In contrast to the stream-rich southern part of the Ti-a, its northern part has no perennial stream. While the southern outcrop of Ti-a lies at lower altitude than adjacent permeable rocks ( $Q b, Q p$ and Qva), the northern part is projecting above the adjacent permeable rocks (Qva and Qp). The Quaternary impermeable domes of Qad and Qr-d do not maintain perennial streams except on the foot of a Qr-d dome along the contact with overlying permeable $\mathrm{Qb}$.

Qa recorded the maximum length of perennial streams $(72.7 \mathrm{~km}$ or $50.3 \%$ of the total length in whole area). None of them, however, was infested with $S$. ochraceum larva. They are too gently sloped for breeding of S. ochraceum.
Comparing between geologic ages, older rocks showed higher density of ochraceumbreeding streams. In general, older rocks have more chance of being overlain by other rocks than younger ones. Furthermore, comparing between lahars of Qva and Ti-a, the older ones ( $\mathrm{Ti}-\mathrm{a})$ are more cemented and less permeable than the younger ones (Qva).

Geomorphologic aspects of distribution of $\mathrm{S}$. ochraceum larvae in the study area $B$

The study area $B$ lies on the southwestern quarter of the study area A. It is composed of southern part of Ti-a and adjacent part of Qp (Fig. 1), and roughly coincides with the endemic area of onchocerciasis (Unpublished document of the Departamento de Oncocercosis, SNEM, Guatemala). In the study area B, distribution of streams was studied with respect to channel network. All the channel segments shown in the drainage map were visited by on-foot surveys.

Table 3 summarizes the number and length 
Table 3. Number and length of channel segments, perennial streams and ochraceum-breeding perennial streams for different channel orders in the study area $B$.

\begin{tabular}{|c|c|c|c|c|c|c|c|c|}
\hline \multirow{2}{*}{\multicolumn{2}{|c|}{ Item }} & \multicolumn{7}{|c|}{ Channel order } \\
\hline & & 0 & 1 & 2 & 3 & 4 & 5 & Total $^{1)}$ \\
\hline \multirow{3}{*}{$\begin{array}{l}\text { Channel segment } \\
\text { (A) }\end{array}$} & No. & - & 1206 & 212 & 42 & 8 & 1 & 1469 \\
\hline & Total length, km & - & 126.8 & 41.5 & 18.2 & 12.7 & 2.5 & 201.7 \\
\hline & Mean length, km & - & 0.11 & 0.20 & 0.43 & 1.59 & 2.5 & 0.14 \\
\hline \multirow{3}{*}{$\begin{array}{l}\text { Perennial stream } \\
\text { (B) }\end{array}$} & No. & 21 & 90 & 70 & 34 & 8 & 1 & 203 \\
\hline & Total length, $\mathrm{km}$ & 1.0 & 9.5 & 12.3 & 10.8 & 12.7 & 2.5 & 47.8 \\
\hline & Mean length, $\mathrm{km}$ & 0.05 & 0.11 & 0.18 & 0.32 & 1.59 & 2.5 & 0.24 \\
\hline \multirow{3}{*}{$\begin{array}{l}\text { ochraceum-breeding } \\
\text { perennial stream } \\
\text { (C) }\end{array}$} & No. & 17 & 57 & 40 & 11 & 0 & 0 & 108 \\
\hline & Total length, km & 0.7 & 5.4 & 4.2 & 2.0 & 0.0 & 0.0 & 11.6 \\
\hline & Mean length, $\mathrm{km}$ & 0.04 & 0.09 & 0.11 & 0.18 & - & 一 & 0.11 \\
\hline \multirow[t]{2}{*}{$\mathrm{B} / \mathrm{A}, \%$} & No./no. & - & 7.5 & 33.0 & 81.0 & 100.0 & 100.0 & 13.8 \\
\hline & Length/length & - & 7.5 & 29.6 & 59.3 & 100.0 & 100.0 & 23.7 \\
\hline \multirow[t]{2}{*}{$\mathrm{C} / \mathrm{B}, \%$} & No./no. & 81.0 & 63.3 & 57.1 & 32.4 & 0.0 & 0.0 & 53.2 \\
\hline & Length/length & 70.0 & 56.8 & 34.1 & 18.5 & 0.0 & 0.0 & 24.3 \\
\hline
\end{tabular}

1) The 0'th order is excluded.

of channel segments, perennial streams and the ochraceum-breeding perennial streams for channel order. Of total 1469 channel segments, only $203(13.8 \%)$ were found maintaining perennial running water, of which $108(53.2 \%)$ were infested with $S$. ochraceum. In addition to those streams on the channels registered in the drainage map, 21 perennial streams were found on the 0'th order channels, or those which are too small to be detected in the topographic map in $1: 50,000$ scale. Of these 21 streams, 17 $(81.0 \%)$ were infested with $S$. ochraceum larvae.

The higher the order, the greater part of the channel segments were filled with perennial running water. It seems natural because the higher order channels have greater basin area, and thus greater chance of collecting water than the lower order ones. On the other hand, the ratio of perennial streams with $S$. ochraceum larvae decreased with order. It was observed in the field that higher order channels have smaller channel slopes, and are less favorable for breeding of $S$. ochraceum than the lower order ones. Channel segments of the fourth and fifth order were totally filled with perennial running water, but no $S$. ochraceum larva was found there. As to the total number and length of ochraceum-breeding streams, the first order channels showed the greatest number (57) and length $(5.4 \mathrm{~km})$, followed by the second order $(40,4.2 \mathrm{~km})$. The first and second order channels contributed as much as $90 \%$ in number and $83 \%$ in length of total ochraceum-breeding streams.

Figure 2 shows the distribution of perennial streams, both with and without $S$. ochraceum larvae in the study area $\mathrm{B}$, together with channel network and contour lines. Of total 119 ochraceum-breeding stream segments, $116(97 \%)$ were found within $1 \mathrm{~km}$ downstream, mostly within $500 \mathrm{~m}$, from the headsprings. Only three were found from lower reaches of tributaries, but none was done from the main channels. Of total 176 headsprings, $116(66 \%)$ harbored $S$. ochraceum larvae immediately downstream. Therefore, the distribution of $S$. ochraceum larvae is strongly related with the distribution of headsprings.

In the field, the neighboring headsprings were often found on the same elevation, suggesting existence of water tables. Nakamura et al. (1981) describes horizontal arrangement of headsprings along the contour line of $1300 \mathrm{~m}$ above sea level in the Los 


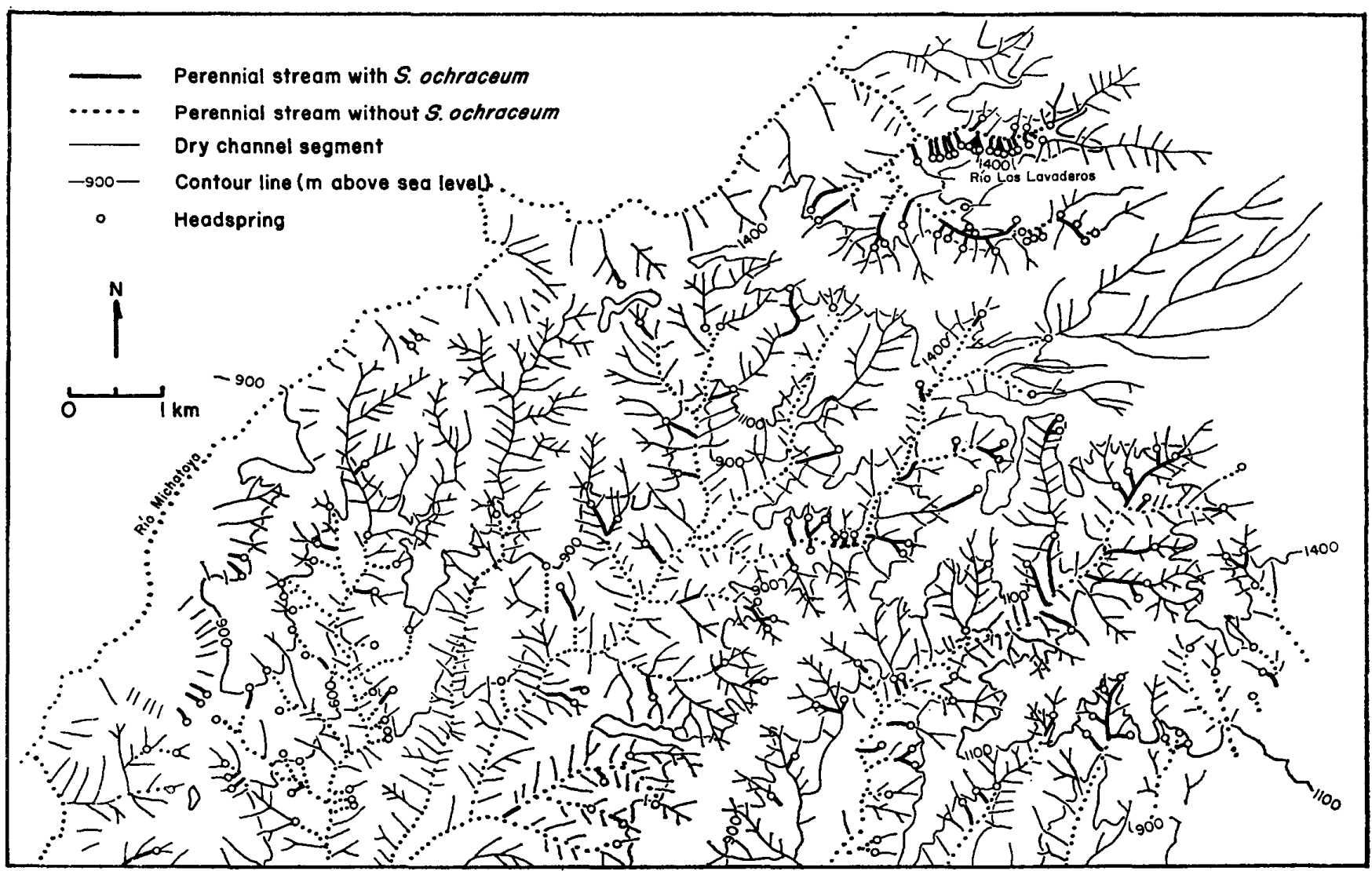

Fig. 2 A drainage map of the study area B, showing the distribution of perennial streams both with and without $S$. ochraceum.

Lavaderos valley. Of total 176 headsprings in the study area B, $56(32 \%)$ were found at around $1400 \mathrm{~m}$ above sea level (1300$1460 \mathrm{~m}), 52(30 \%)$ at around $900 \mathrm{~m}(850$ $940 \mathrm{~m})$ and $16(9 \%)$ at around $1100 \mathrm{~m}$ $(1050-1140 \mathrm{~m})$. In addition, 12 headsprings $(7 \%)$ were found at around $600 \mathrm{~m} \mathrm{(550-}$ $700 \mathrm{~m}$ ) in the western part of the study area $\mathrm{B}$, where the elevation of headsprings lowered toward downstream direction along the main channel.

\section{Discussion}

According to the results of the present study, we suggest the following strategy for the pre-control surveys against $S$. ochraceum: Geologic analysis should be made for the purpose of delimiting ochraceum-rich areas from the preliminary settled control area. In the volcanic region, attention must be paid on older volcanic rocks, which are more important as ochraceum-breeding bed than the younger ones. The topographic map in
$1: 50,000$ or larger scale is necessary for preparing the drainage map, which is an essential tool for conducting systematic surveys. All the channel segments in the drainage map should be visited with special emphasis on the lower order ones. Without a drainage map, some ochraceum-breeding streams on the lower order channels could be easily overlooked. Though the stream symbols in the topographic map describe some large streams on the fourth or higher order channels, they neglect most of the ochraceum-breeding streams on the third and lower order channels. The ochraceumbreeding streams on the 0'th order channels are usually discovered by upstream tracing of every stream branching. Those which escape upstream tracing due to partial underground flow could be detected by horizontal tracing along contour lines from known headsprings.

The infant, young and adolescent streams of Dalmat's classification (1955) roughly corresponded with the 0'th, first to second, 
and third to fourth order channel segments, respectively. The channel order concept is more systematic and a better operational tool for our survey than the empirical concept of stream age by Dalmat.

Strong et al. (1934) reported onchocerciasis patients and their geographical distribution from the Pacific slope of the Sierra Madre volcanic range. Dalmat (1955) explained such a climatological factor for breeding of the vector blackflies that the Sierra Madre range blocks prevailing northeasterly wind and admits heavy seasonal rainfall on the Pacific slope. Although Dalmat could explain one of the reasons of the distribution of onchocerciasis in Guatemala, we should emphasize here that geology is also an essential component in specifying vector breeding streams. As far as the surveyed area is concerned, the volcanic range is composed of both old stream-rich rocks and recent stream-poor ones. Crosskey (1956, 1981) pointed out the distribution of both onchocerciasis patients and the vector species, $S$. damnosum s.l., in Nigeria is associated with Precambrian rocks, which provide rocky river beds adequate for vector breeding.

\section{Acknowledgements}

We are grateful to the staff members of SNEM, both Guatemalan and Japanese, who kindly assisted the study, especially to Dr. Takeshi Suzuki, Leader of the Japanese team, for his critical review of the manuscript. We are also grateful to Col. Eng. Lionel Aníbal Rivera Morataya, Director of the Instituto Geográfico Militar, Ejército de Guatemala, for his kind permission to the reproduction of the geologic map in this paper.

\section{REFERENCES}

Crosskey, R. W. (1956): The distribution of Simulium damnosum Theobald in Northern Nigeria. Trans. R. Soc. Trop. Med. Hyg., 50: 379-392.

Crosskey, R. W. (1973): Simuliidae (Black-flies, German: Kriebelmücken). In: Insects and Other Arthropods of Medical Importance. (ed., Smith, K. G. V.), pp. 109-153, British Museum, London.

Crosskey, R. W. (1981): A review of Simulium damnosum s.l. and human onchocerciasis in Nigeria, with special reference to geographical distribution and the development of a Nigerian national control campaign. Tropenmed. Parasitol., 32: 2-16.

Dalmat, H. T. (1955): The black flies (Diptera, Simuliidae) of Guatemala and their role as vectors of onchocerciasis. Smithson. Misc. Collect., 125: 1-425.

Davies, J. B. (1974) : Problems facing the control of Simulium species in the onchocerciasis zones of Mexico. PAHO Scientific Publication No. 298: 96-99.

Horton, R. E. (1945) : Erosional development of streams and their drainage basins; hydrophysical approach to quantitative morphology. Geol. Soc. Am. Bull., 56: 275-370.

McMahon, J. P. (1967): A review of the control of Simulium vectors of onchocerciasis. Bull. WHO, 37: 415-430.

Nakamura, Y., Y. Yamagata, H. Takaoka, M. Takahashi, J. O. Ochoa A., P. A. Molina and H. Takahasi (1981): A control trial of the vector of onchocerciasis, Simulium ochraceum (Diptera: Simuliidae) in the Lavaderos River Valley, Guatemala. Jap. J. Sanit. Zool., 32: 51-58.

Strahler, A. N. (1957): Quantitative analysis of watershed geomorphology. Trans. Am. Geophys. Union, 38: 913-920.

Strong, R. P., H. J. Sandground, J. C. Bequeart and M. Muñoz Ochoa (1934): Onchocerciasis, with special reference to the Central American form of the disease. Contrib. Dep. Trop. Med. and Inst. Trop. Biol. and Med., Harvard Univ., No. 6: 234 pp.

Takaoka, H., J. O. Ochoa A., M. Takahashi and H. Takahasi (1981): Evaluation of temephos as a larvicide against Simulium ochraceum (Diptera: Simuliidae) in Guatemala. J. Med. Entomol., 18: 145-152.

\section{摘 \\ グァテマラにおける Simulium ochraceum の分布に関する地質・地形学的研究}

グァテマラのオンコセルカ症流行地で, 主要媒介種 である Simulium ochraceum の発生源の分布を調査 し，地質および地形々の関係を検討した。 調査面積 $477 \mathrm{~km}^{2}$ 内で計 246 本 $(144.4 \mathrm{~km})$ の不断水流が発見 もしくは確認され，うち 119 本 $(48.4 \%) 27.8 \mathrm{~km}$ (19.3\%) で S. ochraceum の発生が認められた. $S$. ochraceum 幼蚔主として古い不透水性の岩に分布 していた.これに対して新しい火山岩は透水性が高 く, 不断水流を保持しないため, S. ochraceum の発 生に不適だが, 不透水性岩の上に位置した時, 地下水 の供給源として重要になる. 沖積地では水流密度が高 かったが,これらの水流ではまったくS. ochraceum の発生が見られなかった。第三紀泥流・溶岩地帯は $S$. 
ochraceum の発生源を最も多く有し，かつオンコセ ルカ症流行地とも一致した。 この地帯 $\left(77 \mathrm{~km}^{2}\right)$ にあ る計 1469 本の谷セグメントを踏查した結果, 203 本 (13.8\%) 方不断水流を持ち，このうち 108 本 (53.2\%) がS. ochraceum の発生源となっていた. 谷次数が高 くなる下流ほど, 谷セグメントが不断水流を持つ率が
高くなったが，それらの水流が S. ochraceum を発生 させる率は逆に低くなった.S.ochraceumの分布は， 主として源流の湧泉から下流 $1 \mathrm{~km}$ 以内の谷次数の低 い谷セグメントに多く見られた．涌泉は主として海抜 $900 \mathrm{~m}, 1100 \mathrm{~m}, 1300-1460 \mathrm{~m}$ の 3 段階の高度に沿っ て，ほぽ水平に分布していた。 